\title{
A NEW SPECIES OF NEOCAECULUS (ACARI: PROSTIGMATA: CAECULIDAE) FROM BARROW ISLAND, WESTERN AUSTRALIA, WITH A CHECKLIST OF WORLD CAECULIDAE
}

\author{
Christopher K. TAYLOR ${ }^{1,}{ }^{*}$, Nihara R. GUnAWARDENE ${ }^{1}$ and Adrianne KINNEAR ${ }^{2}$ \\ (Received 10 May 2013; accepted 17 July 2013; published online 19 December 2013) \\ ${ }^{1}$ Dept of Environment and Agriculture, Curtin University of Technology, GPO Box U1987, Perth, WA 6845, Australia. $\left({ }^{*}\right.$ Corresponding author). \\ Chris.Taylor@curtin.edu.au, N.Gunawardene@curtin.edu.au \\ ${ }^{2}$ Faculty of Computing, Health and Sciences, Edith Cowan University, 1000 Joondalup Drive, Joondalup, WA 6027, Australia. \\ a.kinnear@ecu.edu.au
}

ABSTRACT - Neocaeculus imperfectus new species is described from material collected on Barrow Island, Western Australia. Keys to genera and Australasian species of Caeculidae are provided, and the relationship between the genera Neocaeculus and Microcaeculus is discussed. A checklist of species for Caeculidae is provided.

KEYWORDS — rake-legged mites; Acarina; taxonomy

\section{INTRODUCTION}

Barrow Island off the coast of northern Western Australia has been both a Class A nature reserve since 1910, and a working oil field since 1967. Recently, authorisation was given to begin construction of a liquefied natural gas (LNG) plant on Barrow Island, but with numerous conditions in place to minimise the impact on the island's value as a nature reserve. As part of the environmental monitoring requirements for the plant development, ongoing investigations have been conducted of the terrestrial invertebrate fauna of Barrow Island (Callan et al., 2011). Certain species of invertebrate have proven to be extremely abundant on the island. One such species is a mite of the family Caeculidae. Samples taken from vegetation at all localities surveyed contained large numbers of individuals of this species, often several dozen in a single sample. Nevertheless, despite this species' numerical dominance at this locality, it has not been previously described and represents a new species to science.

The Caeculidae are a family of large, strongly sclerotised mites found worldwide in arid habitats such as deserts and mountains (Otto, 1993; Walter et al., 2009). They are commonly referred to as 'rakelegged mites' due to the presence of elongate spinelike setae on the legs, particularly the first pair, of most species. These spines are used in the capture of smaller arthropods such as Collembola as prey (Otto, 1993). The morphology, ontogeny and natural history of caeculids were reviewed in detail by Coineau (1974a).

The caeculid fauna of Australia has been very little investigated, with only five species described 
to date from that continent. These comprise four species of the genus Neocaeculus Coineau, 1967a, N. bornemisszai Coineau and Enns, 1969, N. knoepffleri Coineau and Enns, 1969, N. johnstoni Coineau, 1974b and N. womersleyi Coineau, 1974b, and one of Microcaeculus Franz, 1952, M. pica Otto, 1993. A record of Caeculus Dufour, 1832 from Australia by Mulaik and Allred (1954) was regarded as doubtful by Otto (1993). The Barrow Island species represents a new member of Neocaeculus.

\section{MethodS}

Specimens were mostly collected from vegetation using a modified blower-vac; a smaller number were recovered from pitfall traps. Specimens were observed in $70 \%$ alcohol after partial clearing in $50 \%$ lactic acid using a Nikon SMZ1500 stereo microscope; selected specimens were further cleared and slide-mounted using Hoyer's mountant for observation of finer features using a Leica DM2500 compound microscope. Measurements and photographs were taken from the stereo microscope using the NIS-Elements D program; measurements are given in micrometres as means, with the measured range in parentheses; ten adult specimens were measured.

Setae are generally described as clavate, spinose or filiform. Clavate setae are broad and flattened with extensively divided margins; spinose setae are elongate and thick, and when examined at high magnification can be seen to be minutely divided, particularly terminally; filiform setae are fine and entirely undivided. It should be noted, however, that variation in setal morphology is continuous and setae may be intermediate between these classes; the distinction between an elongate clavate seta and a short spinose seta may be somewhat subjective.

Specimens are held by J. Majer, Curtin University; type specimens are to be deposited in the Western Australian Museum, Perth, Australia (WAM).

\section{TAXONOMY}

\section{Neocaeculus Coineau, 1967a}

Type species. Neocaeculus luxtoni Coineau, 1967a, by original designation.

Included species. N. luxtoni, N. bornemisszai Coineau and Enns, 1969, N. bruchi (Berlese, 1916), N. imperfectus n. sp., N. johnstoni Coineau, 1974b, N. knoepffleri Coineau and Enns, 1969, N. lamorali Coineau, 1974a, N. womersleyi Coineau, 1974b.

\section{Neocaeculus imperfectus n. sp. Figures 1-3}

Holotype - Adult female, gas treatment plant site, Barrow Island, Western Australia, N. Gunawardene, C. Taylor, 14-24 March 2011, suction (WAM).

Paratypes - Numerous adults and nymphs, as for holotype (WAM).

Other material - Specimens of this species have been collected in numerous samples over several years on Barrow Island, Western Australia. The greater number of specimens have been collected via suction of vegetation; smaller numbers of specimens have been collected in pitfall traps.

Etymology - Latin imperfectus, incomplete, referring to the retention of juvenile characters (particularly the lower number of setae) into maturity by this species.

Dorsum (Figures 1A-B) - Idiosoma length 1036 (885 - 1147), width 599 (525 - 663). Cream-coloured sclerites divided by black striated integument. All sclerites with reticulate ornamentation of raised ridges. Aspidosomal sclerite with median rectangular area outlined by dark-pigmented grooves; aspidosomal sclerite length 325 (268 - 375), width 342 (287 - 370); setae $P a$ situated at anteriormost corners of sclerite; setae $P m$ at 0.2 on anterior lateral corners of sclerite; setae $P p$ at 0.7 towards posterior lateral corners of sclerite. Two pairs of eyes on accessory sclerite lateral to rear of aspidosomal sclerite; anterior margin of anterior eyes roughly level with setae $P p$. Centrodorsal sclerite with paired setae $a 1, b 1, c 1$ present; centrodorsal sclerite length 452 (404-515), width $333(303-363)$. Lateral sclerites 

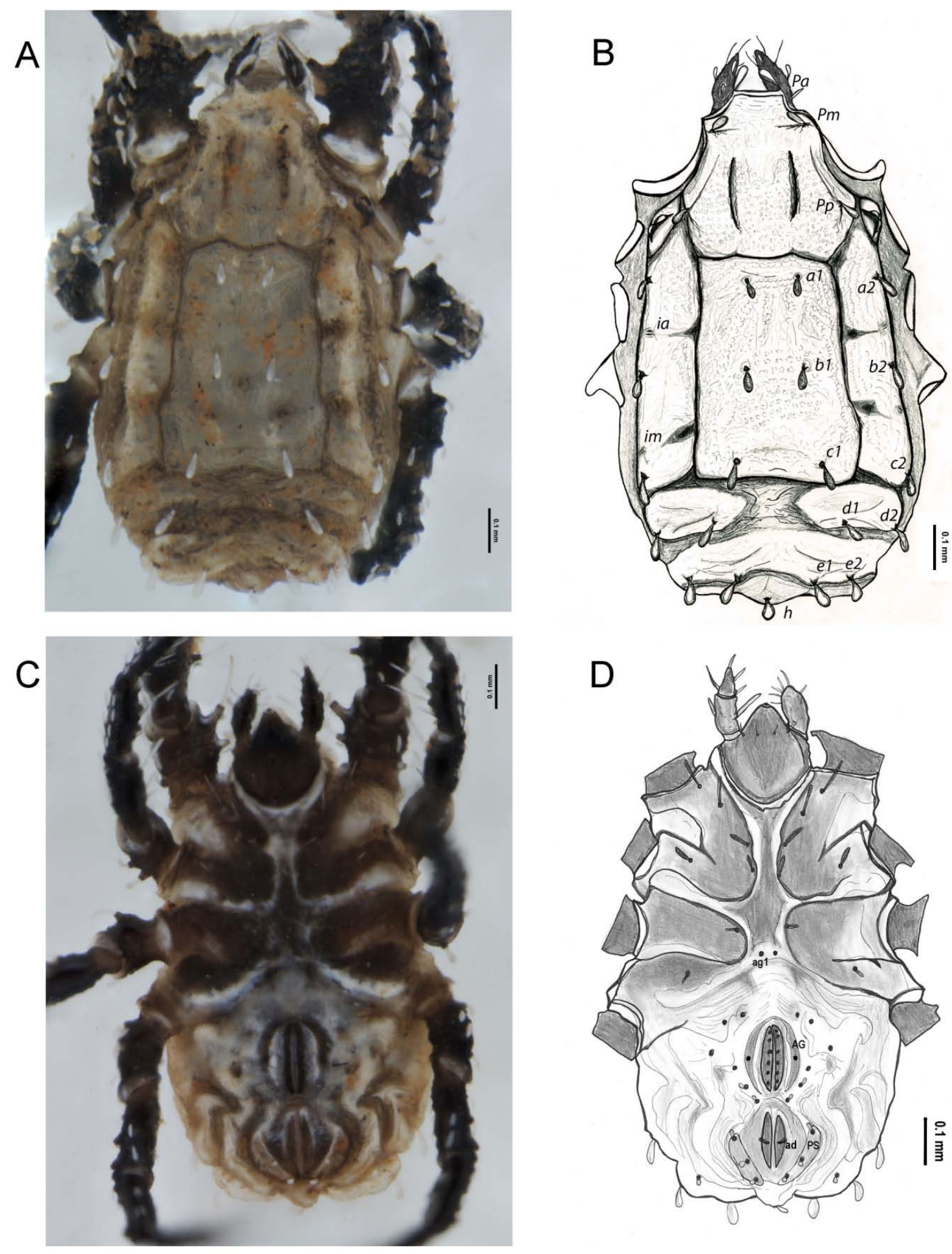

FIGURE 1: Neocaeculus imperfectus, idiosoma: A - photograph of dorsum; B - schematic drawing, with representative seta and lyrifissure labels; C - photograph of venter; D - schematic drawing (locations of smaller setae marked with black dot), with labels showing position of setae $a g 1$ and adanal setae (ad), aggenital sclerite (AG) and pseudanal sclerite (PS). 

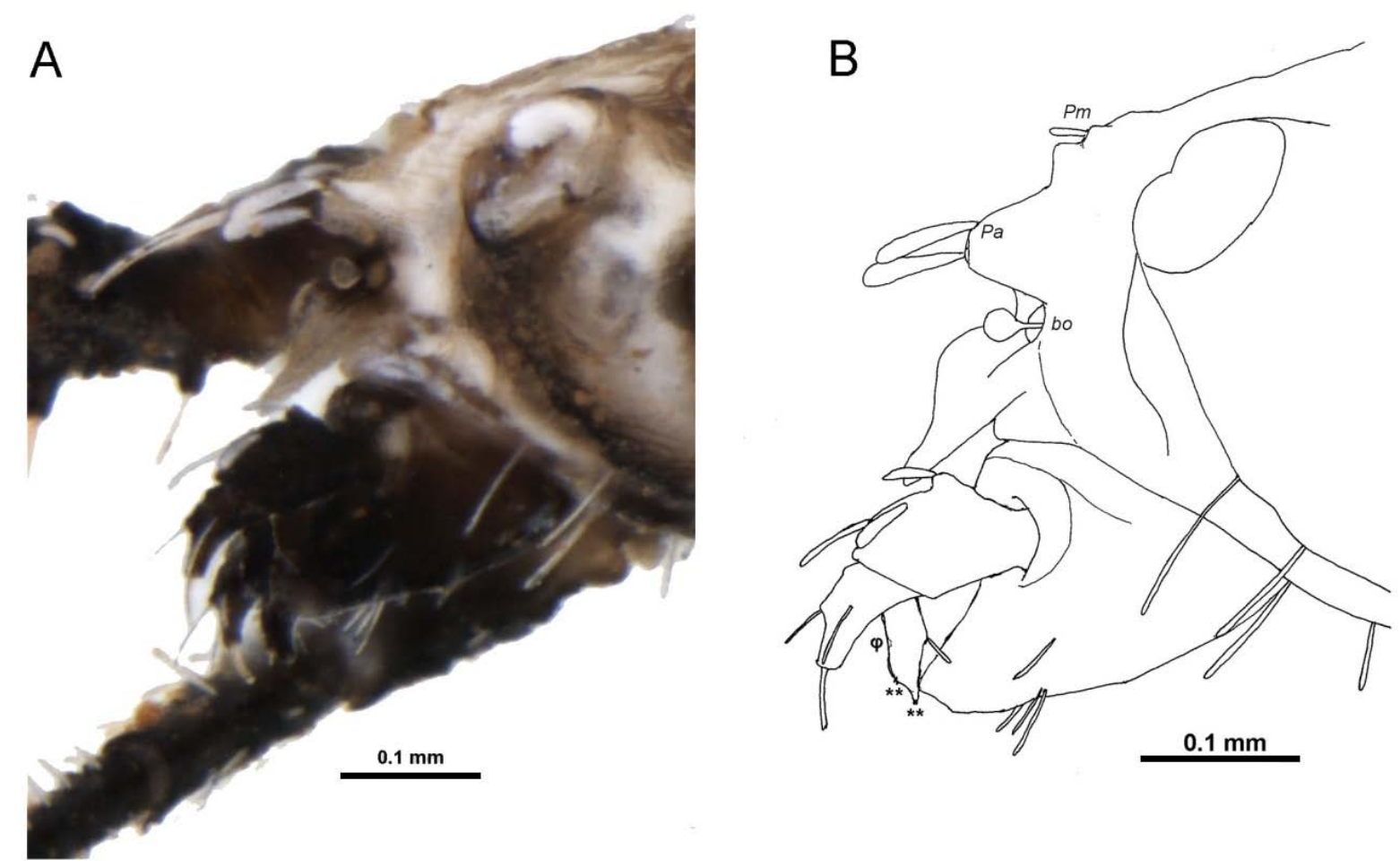

FIGURE 2: Neocaeculus imperfectus, gnathosoma, lateral view: A - photograph; B - schematic drawing, with representative seta labels: eupathidia marked with asterisk $\left(^{*}\right)$, position of solenidion marked with $\varphi$.

each subdivided by two transverse pigmented depressions; paired setae $a 2, b 2, c 2$ sequentially placed with one seta on each sub-region of sclerite demarcated by depressions; lyrifissure ia transverse, about one-sixth width of lateral sclerite, placed roughly two-thirds of distance posteriad between $a 2$ and $b 2$; lyrifissure im angled laterally rearwards, similar in size to $i a$, placed about two-thirds of distance posteriad between $b 2$ and $c 2$. Idiosoma with broadly separated medial sclerites bearing setae pairs $d 1, d 2$, two separated or one transverse posterior sclerites bearing setae pairs $e 1, e 2$, and pluriposterior accessory sclerite bearing upaired seta $h s$ with paired setae $h$ on striated cuticle lateral to $h s$. Setae $d s$ and es absent.

Venter (Figures 1C-D) - Epimeres grey-brown; epimeres I separated from gnathosoma by cream collar with cream stripes internal to epimeres I and II, median integument between epimeres I and II and entire integument between epimeres III and IV grey-brown; venter of idiosoma largely cream ex- cept genital valves dark brown, black stripe external to pseudanal sclerites. Median eye present just behind underside of anterior projection of aspidosomal sclerite; large bothridial setae bo present lateral to median eye, with nodulose pyriform caput. Epimere I fused with II, epimere I with four anterior barbed setae with basalmost seta placed close to junction between epimeres I and II, epimere II with one anterior barbed seta close to base; epimere III fused with IV, epimere III with one barbed seta close to anterior medial corner, epimere IV with one barbed seta close to base. Genital valves with six to eight pairs of setiform setae, with setae on each valve somewhat staggered; genital opening length 151 (119-163). Eight pairs of aggenital setae present, with one pair of setiform setae on aggenital sclerites; anteriormost pair of clavate aggenital setae ag1 close to level of anterior of epimere IV; one pair of setiform setae directly anterior to aggenital sclerites; two pairs of barbed setae roughly lateral to anterior ends of aggenital sclerites; remaining four 
pairs of barbed or clavate setae forming series running from about level of midline of aggenital sclerites to near posterior ends of aggenital sclerites, with anteriormost pair furthest laterad from aggenital sclerites and posteriormost pair close to aggenital sclerites. Anal valve with one pair clavate setae; pseudanal sclerites with one to three pairs clavate setae; anal opening length 145 (135 - 168).

Gnathosoma (Figure 2) - Gnathosoma uniformly dark brown. Gnathosoma base with two pairs of setiform setae, with median pair placed slightly anterior of lateral pair. Rostral lobes each with distal pair of small setiform setae. Palp with four segments; fused femur-genu with three dorsal barbed setae; tibia with five setae (three dorsal spiniform setae at about mid-length; one proximal anterior ventrolateral setiform seta and one terminal spiniform seta); tarsus with three ventral spinose setae at about 0.5 , one dorsal solenidion at about 0.5 , and four eupathidia (two paired eupathidia at distal end, two separated dorsal eupathidia close to distal end).

Legs (Figure 3) - Legs black with white setae. Setae of all legs (from the femur onwards) are arranged more or less into five rows that are referred to here as the anterior dorsolateral, median dorsal, posterior dorsolateral, anterior ventrolateral and posterior ventrolateral rows; the median dorsal row on each leg generally only reaches to about halfway along the tibia, so the distal half of the tibia and the tarsus only bear four rows of setae. Dorsal setae are generally short clavate from the trochanter to the genu, becoming more elongate and spinose on the tibia and tarsus. Leg I with anterior ventrolateral and posterior ventrolateral setae borne on long tubercles; femur I with one proximal elongate clavate and one medial spinose seta in each of anterior ventrolateral and posterior ventrolateral rows; genu I with three pairs of anterior ventrolateral and posterior ventrolateral spinose setae, distal two anterior ventrolateral setae longer than proximalmost seta, posterior ventrolateral setae with median seta longer than distal seta which is in turn longer than proximal seta; tibia I with three pairs of anterior ventrolateral and posterior ventrolateral spinose setae, with distal setae longer than proximalmost seta in both anterior ventrolateral and posterior ventrolateral rows, hidden solenidion present distal to eupathidium at distal end of posterior dorsolateral row, with regressed seta k" immediately dorsal to solenidion; tarsus I with three pairs of anterior ventrolateral and posterior ventrolateral small spinose setae, anterior lateral solenidion present at 0.5 below distal anterior dorsolateral eupathidium, distal end of tarsus with three anterior lateral, one posterior dorsolateral and one posterior ventrolateral small solenidion, and one posterior lateral cone-shaped seta; claws unequal with anterior claw smaller. Femur II with two large anterior ventrolateral clavate setae (distal seta longer than proximal), one posterior ventrolateral short spinose seta at 0.5 ; genu II with two anterior ventrolateral spinose setae, two posterior ventrolateral small spinose setae; tibia II with four anterior ventrolateral spinose setae, five posterior ventrolateral small spinose setae, posterior dorsolateral distal hidden solenidion; tarsus II with five anterior ventrolateral and posterior ventrolateral small spinose setae, anterior lateral hidden solenidion at 0.5 , distal end of tarsus with one anterior dorsolateral cone-shaped seta; claws unequal with anterior claw smaller. Femur III with two anterior ventrolateral clavate setae, one posterior ventrolateral small spinose seta; genu III with three anterior ventrolateral clavate setae, two posterior ventrolateral small spinose setae; tibia III with five anterior ventrolateral clavate setae, five posterior ventrolateral small spinose setae; tarsus III with four anterior ventrolateral and posterior ventrolateral spinose setae, distal end of tarsus with two ventral and one posterior lateral horn-shaped setae, one anterior dorsolateral spinose seta, elongate dorsal bothridial seta $b t$ slightly behind distal anterior dorsolateral seta; claws subequal, anterior claw only slightly smaller. Femur IV with two anterior ventrolateral clavate setae, one posterior ventrolateral small spinose seta; genu IV with one anterior ventrolateral clavate seta, one posterior ventrolateral small spinose seta; tibia IV with five anterior ventrolateral and posterior ventrolateral spinose setae, one distal posterior lateral hidden solenidion; tarsus IV with four anterior ventrolateral and posterior ventrolateral spinose setae, distal end of tarsus with two ventral large cone-shaped setae, one posterior 

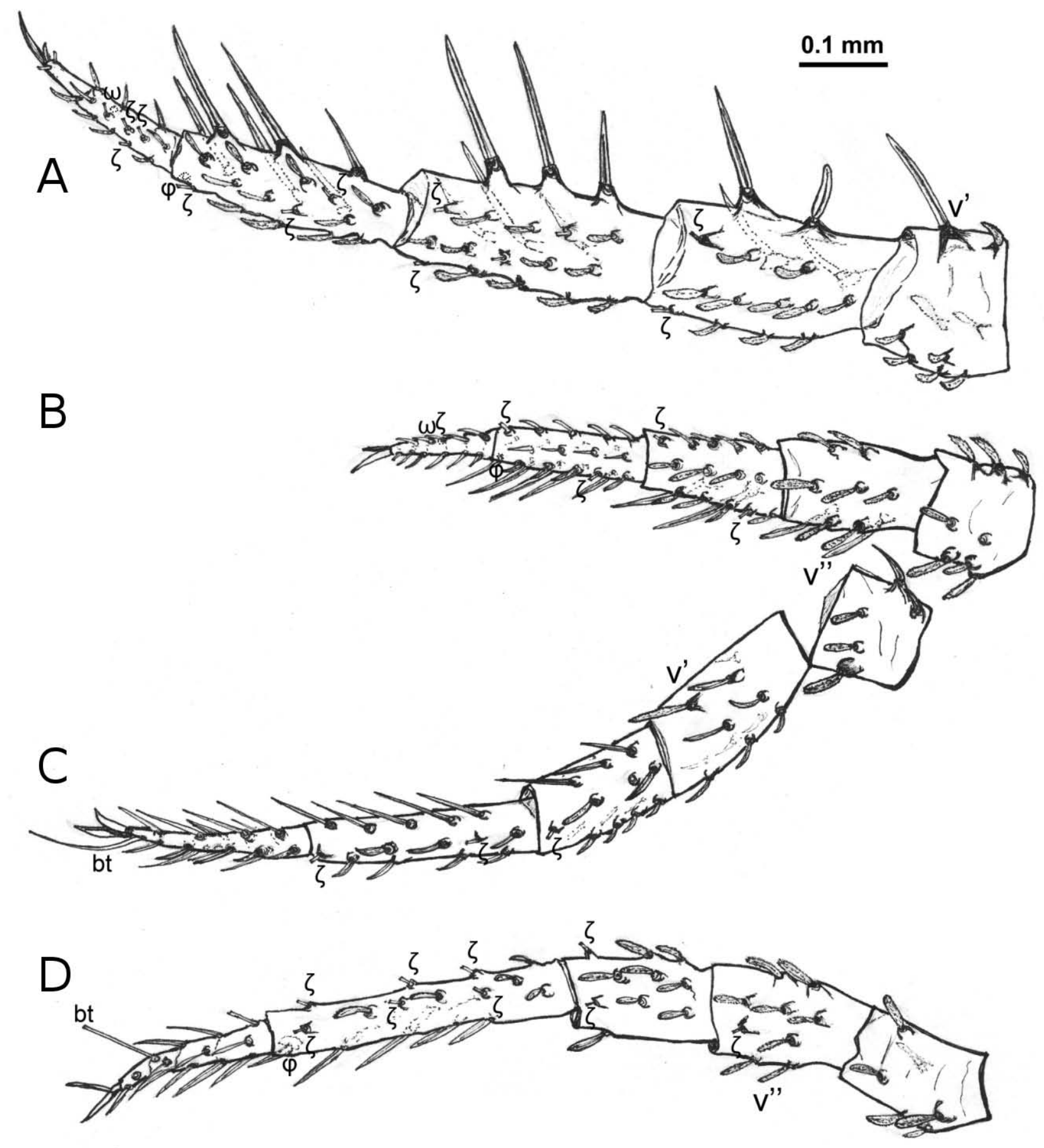

FIGURE 3: Neocaeculus imperfectus, legs. A - Leg I in anterior dorsolateral view; B - Leg II in dorsal view; C - Leg III in anterior dorsolateral view; D - Leg IV in posterior dorsolateral view.

Position of eupathidium marked with $\zeta ; \varphi$ marks position of hidden tibial solenidion; $\omega$ marks position of hidden tarsal solenidion; bt marks tarsal bothridium. The first visible ventrolateral spine is marked on each leg to facilitate orientation; $\mathrm{v}^{\prime}$ indicates the anterior ventrolateral row, $\mathrm{v}$ " indicates the posterior ventrolateral row. 
lateral cone-shaped seta, elongate dorsal bothridial seta $b t$ about halfway between level of third and fourth anterior dorsolateral setae.

Nymphal stages - Dorsal setation as for adult female. Genital and anal openings successively smaller and less sclerotised; fewer aggenital setae. Epimere I with four setae in tritonymph, three setae in deutonymph and protonymph. Enlarged ventrolateral leg setae similar to adult in tritonymph and deutonymph, though proximal anterior ventrolateral clavate seta on femur I successively smaller in each instar; protonymph leg I with one anterior ventrolateral and posterior ventrolateral large spinose seta on femur I; two anterior ventrolateral and one posterior ventrolateral large spinose seta on genu I; two anterior ventrolateral and two posterior ventrolateral large spinose setae on tibia I.

Variation - Variation in dorsal setation was very uncommon. A single tritonymph was observed with a second slightly smaller pair of setae $P p$ behind the usual pair on the aspidosomal sclerite. Two individuals were also observed in which the setal pair $d 2$ was doubled (in one of these individuals, on one side only). Variation in ventral and leg setation was more common. At least one larger individual was found with five rather than four setae on epimere I; epimere setae could also vary noticeably in length, being short clavate in some individuals and more elongate in others. Dorsal leg setae could vary in number between individuals. Supernumerary accessory dorsal setae were not uncommon, but the number and arrangement of the larger ventral setae were mostly consistent with variants being very rare.

Comments - Compared to other species in Caeculidae (reviewed by Coineau, 1974a), Neocaeculus imperfectus is remarkable in the relative constancy of its setation between instars and can be described as a true neotenous form. Despite the observation of specimen numbers probably into the hundreds, no males have been identified, and the species is probably parthenogenetic.

Neocaeculus imperfectus can be assigned to Neocaeculus by the features given in the key to caeculid genera below. Among other Australasian species of Caeculidae, it differs from N. bornemisszai and
$N$. knoepfleri in the shape of bo (globose-capitate vs brush-like and non-capitate; Coineau and Enns 1969). Neocaeculus imperfectus can be distinguished from N. luxtoni and Microcaeculus pica by the absence of the dorsal median accessory setae $d s$ and $e s$, and in the presence of large spinose setae on trochanter and femur I (Coineau 1967a; Otto 1993). It differs from $N$. johnstoni and N. womersleyi in having femur I undivided (Coineau 1974b).

Coineau (1974a) assigned two species from outside Australasia to Neocaeculus, the southern African N. lamorali and the South American N. bruchi (miscited by Coineau, 1974a, as 'N. brucki'). Both these species have, to date, received only brief descriptions, and potentially important features such as bothridial morphology remain undescribed for both. Neocaeculus lamorali may be distinguished from Australasian species by the presence of two pairs of setae $P p$ and the presence of paired setae instead of a single seta es (Coineau, 1974a). The initial description of 'Caeculus' bruchi by Berlese (1916) is probably inadequate for its identification, and it was listed as a species incertae sedis by Franz (1952). Coineau (1974a) referred to it as a Neocaeculus species without redescribing it in detail, commenting only on a single aspect of this species' setal morphology. The distal setae er on the leg tarsi of $N$. bruchi are rounded, divergent from the tarsus, and enlarged to a diameter half that of the tarsus, rather than being flattened, distally directed, and relatively smaller in most other species (Coineau, 1974a).

\section{COMMENTS ON RECOGNITION OF Neocaeculus}

Coineau (1967a) established a new genus Neocaeculus for the New Zealand species N. luxtoni on the basis that it possessed a reduced dorsal setation like that of Microcaeculus hispanicus, but did not have the aspidosomal sclerite extended forward over the gnathosoma as in Microcaeculus. He also noted two further features as unique to the new genus: the undivided femora in the legs, and the presence of a distal solenidion on tibia IV. Coineau and Enns (1969), in describing two new species of Neocaecu- 
lus, provided a list of principal characteristics for the genus: reduced dorsal setation, an enlarged median eye, a single pair of adanal setae, undivided femora, unequal tarsal claws, the distal solenidion of tibia IV, and an antilateral famulus.

The majority of these features are not unique to Neocaeculus. A reduced dorsal setation is also found in some Microcaeculus species (Coineau, 1974a), as is an enlarged median eye (Coineau, 1968), solenidion on tibia IV (Coineau, 1969b; Otto, 1993) and an antilateral famulus (Coineau, 1968; Coineau and Haupt, 1977). Unequal tarsal claws are found in Microcaeculus, Allocaeculus, Andocaeculus and Calocaeculus (Coineau, 1974a). Coineau (1974b) later assigned two Australian species to Neocaeculus that had the femora divided into two segments as in other caeculid genera (undivided femora are also present in Procaeculus, but an immediate relationship between Procaeculus and Neocaeculus within Caeculidae seems unlikely - Coineau, 1974a).

A single pair of adanal setae is also found in the Australian species Microcaeculus pica (Otto, 1993), which also shares a number of features with particular Neocaeculus species that are otherwise not recorded for Microcaeculus. Its femora are undivided as in Neocaeculus luxtoni, N. knoepffleri, $N$. bornemisszai and N. imperfectus. The globosecapitate and relatively short bothridium bo morphology found in M. pica, N. luxtoni and N. imperfectus has not been recorded from any other species of Caeculidae, in which bo is mostly elongate with the caput narrow or absent (Coineau 1974a). These characters raise the possibility that $M$. pica may be more closely related to other Australian species in Neocaeculus than to its current congeners in Microcaeculus.

Overall, Microcaeculus and Neocaeculus are effectively distinguished from each other at present by a single character, the anterior expansion (Microcaeculus) or not (Neocaeculus) of the aspidosomal sclerite. In light of the conflict in distribution between this and other potentially significant characters, both Microcaeculus and Neocaeculus deserve a more detailed phylogenetic study in order to test their relative monophyly. Unfortunately, potentially important features such as bothridial and leg morphology remain undescribed for many species in both genera.

\section{Key to Genera of Caeculidae}

1. Tarsal claws of leg I equal in size........... - Tarsal claws of leg I unequal............... 3 2. Anterior margin of aspidosomal sclerite concave, gnathosoma entirely visible from above..................... Procaeculus Jacot, 1936 - Anterior margin of aspidosomal sclerite convex...................... Caeculus Dufour, 1832 3. Dorsodistal bothridia bt present on legs I and II.................. Andocaeculus Coineau, 1974a - Dorsodistal bothridia $b t$ absent on legs I and II................................... 4 4. Anterior half of aspidosomal sclerite extensively neotrichous................Allocaeculus Franz, 1952 - Anterior half of aspidosomal sclerite not neotrichous, aspidosomal sclerite with three pairs of setae or, if more, supernumerary setae in posterior part of sclerite only ...................... 5 5. Dorsal sclerite neotrichous.................... Calocaeculus Coineau, 1974a

- Dorsal sclerite with three or fewer pairs of setae

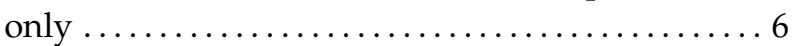
6. Aspidosomal sclerite expanded anteriorly, overhanging gnathosoma in lateral view.................. Microcaeculus Franz, 1952 - Aspidosomal sclerite not anteriorly expanded............... Neocaeculus Coineau, 1967a

\section{Key to Australasian species of Caeculidae}

1. Bothridial setae $b o$ with globular caput........ 2

- Bothridial setae bo elongate, non-capitate ..... .4

2. Dorsal setae $d s$ and es both present; enlarged setae on femur I clavate ................... 3 - Dorsal setae $d s$ and es absent; femur I bearing large spinose setae.......... Neocaeculus imperfectus 3. Genu I with pair of large spinose setae; epimere I with three and epimere II with one seta.......................... Neocaeculus luxtoni - Enlarged setae on genu I clavate; epimere I with 4-6 and epimere II with 3-5 se-

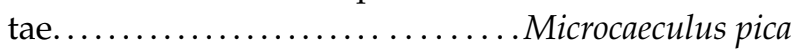


4. Femur I divided (leg I with six post-coxal segments) ............................. 5

- Femur I undivided (leg I with five post-coxal

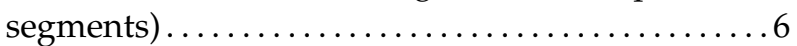
5. Elongate bothridial seta $b t$ present on tarsi III and IV .................... Neocaeculus womersleyi - Bothridial setae $b t$ absent on all tarsi. ........................ Neocaeculus johnstoni 6. Leg I bearing large spinose setae.......................Neocaeculus knoepffleri - All enlarged setae on leg I clavate............ . Neocaeculus bornemisszai

\section{SPECIES LiST FOR CAECULIDAE}

No complete list of species of Caeculidae has been published since Franz (1952), and the taxonomic literature is somewhat scattered. Coineau (1974a) provided an extensive review of the family, but was primarily focused on ontogeny and comparative morphology rather than taxonomy per se. We take the opportunity here to present an up-to-date checklist for the Caeculidae. Taxa are listed alphabetically in their current combinations with synonyms; fossil taxa are marked with a dagger $(\dagger)$. The original descriptions of Caeculus senegalensis André, 1938 and C. uchidai Asanuma, 1940 allow them to be recognised as species of Allocaeculus and Microcaeculus, respectively, and they are transferred to those genera.

New taxa presented in Coineau (1974a) were provided with brief differential diagnoses in a taxonomic appendix. Unfortunately, two new generic names referred to by Coineau (1974a) in the body of the text, Pseudocaeculus and Sclerocaeculus, were omitted from the taxonomic appendix, and cannot be regarded as validly published as they each lack a properly designated type species (ICZN, 1999). Coineau has confirmed that their omission was due to mere oversight (Y. Coineau, personal communication, 2012). We feel that further work is necessary to clarify the status of the taxon groups referred to by each of these generic names, and they are here treated as unavailable names pending such investigation.
Coineau (1974a, p. 59) indicated that Caeculus americanus and other unspecified species were to be placed in a new genus 'Pseudocaeculus' but did not directly indicate any reason for doing so other than the fusion of each of the medial and posterior sclerite pairs into a single unpaired sclerite. Caeculus americanus Banks, 1899 cannot be regarded as the type species of Pseudocaeculus through monotypy as Coineau's (1974a) reference to 'espèces' rather than 'espèce' on p. 59 is a clear indicator that C. americanus was not intended to be the only species in the new genus. Taken alone, the fusion of the dorsal plates would seem little reason for establishing a new genus, and Coineau did not establish new genera for species in Microcaeculus that similarly varied in the rear dorsal sclerotisation. However, on $p$. 191, Coineau (1974a) discussed C. americanus as one of a group of North American species exhibiting a unique neotrichy of setae $\mathrm{Pa}$ on the aspidosomal sclerite. As Coineau (1974a) had also established the genus Calocaeculus on the basis of its unusual neotrichy pattern, it seems likely that this was also the intended basis for distinguishing Pseudocaeculus. Unfortunately, it is currently unclear from published descriptions alone whether North American species such as Caeculus crossleyi Hagan, 1985 and C. lewisi McDaniel and Boe, 1990 exhibit neotrichy of $P a$ or not. Until such a time as these species can be reviewed in more detail, we treat 'Pseudocaeculus' as a synonym of Caeculus.

For Sclerocaeculus, Coineau (1974a) included the species Caeculus deserticolus Lawrence, 1939 and Microcaeculus namibensis Piffl, 1965, but the association of 'gen. n.' with $S$. namibensis only does not constitute a valid type designation for a new genus published after 1931 (ICZN 1999, Art. 68.2.1). Diagnostic features of Sclerocaeculus were discussed by Coineau (1974a) on pp. 59 (arrangement of dorsal sclerites) and 197 (setation of leg IV). Again, these features remain inadequately described in other species currently assigned to Microcaeculus, and Sclerocaeculus is here retained as a synonym of the latter genus pending further investigation. 


\section{CHECKLIST}

Allocaeculus Franz, 1952 (type species Allocaeculus relictus by original designation)

A. andalusiacus Franz, 1952

A. catalanus Franz, 1954

A. circinatus Coineau, 1974a

A. dubius (Kulczyński, 1901)

= Caeculus dubius Kulczyński, 1901

A. echinatus Franz, 1952

A. erinaceus Coineau, 1974a

A. grandjeani Franz, 1957

A. hirsutus Coineau, 1974a

A. hoggarensis (André, 1936)

= Caeculus hoggarensis André, 1936

A. hystriciformis Franz, 1952

A. hystrix (Lawrence, 1939)

= Caeculus hystrix Lawrence, 1939

A. indicus Piffl, 1959

A. kalahariensis Coineau, 1974a

A. kenyae Franz, 1964

A. kocheri Franz, 1964

A. logonensis Franz, 1957

A. meseticola Franz, 1952

= Caeculus meseticola Franz, 1952

A. mosambicensis (André, 1936)

= Caeculus mossambicensis André, 1936

A. multispinosus Franz, 1955

A. nigeriensis Coineau, 1974a

A. ouadaiensis Franz, 1957

A. pilosus (Lawrence, 1938)

= Caeculus pilosus Lawrence, 1938

A. relictus Franz, 1952

A. sarhroi Franz, 1964

A. schusteri Franz, 1960

A. sclerodermatus (André, 1936)

= Caeculus sclerodermatus André, 1936

A. sculptus (Karpelles, 1893)
= Hoplopus sculptus Karpelles, 1893

= Caeculus sculptus (Karpelles, 1893)

A. senegalensis (André, 1938) new combination

= Caeculus senegalensis André, 1938

A. spathulifer (Michael, 1890)

= Caeculus spathulifer Michael, 1890

A. spinosissimus Franz, 1952

A. spinosissimus rondae Franz, 1952

A. sudanensis (Trägardh, 1905)

= Caeculus sudanensis Trägardh, 1905

A. tenerifae Franz, 1965

A. tschadensis Franz, 1957

A. tschadensis rifensis Franz, 1960

Andocaeculus Coineau, 1974a (type species Microcaeculus brundini by original designation)

A. brundini (Franz, 1962)

= Microcaeculus brundini Franz, 1962

Caeculus Dufour, 1832 (type species Caeculus echinipes by monotypy)

= Hoplopus Canestrini and Fanzago, 1877

(unnecessary replacement name)

= Pseudocaeculus Coineau, 1974a (unavail-

able name)

C. americanus Banks, 1899

= Pseudocaeculus americanus (Banks, 1899)

C. archeri Mulaik, 1945

C. calechius Mulaik, 1945

C. clavatus Banks, 1905

C. cremnicolus Enns, 1958

C. crossleyi Hagan, 1985

C. dorotheae Mulaik, 1945

C. echinipesDufour, 1832

= Hoplopus echinipes(Dufour, 1832)

C. echinipes crosbyi Jacot, 1936

C. gertschi Mulaik, 1945

C. hardyi Mulaik and Allred, 1954

C. hypopachus Mulaik, 1945

C. janetae Higgins and Mulaik, 1957b

C. kerrulius Mulaik, 1945 
C. krantzi Coineau, 1974a

C. lewisi McDaniel and Boe, 1990

C. mariae Higgins and Mulaik, 1957a

C. pettiti Nevin, 1943

C. tipus Mulaik, 1945

C. valverdius Mulaik, 1945

Calocaeculus Coineau, 1974a (type species Calocaeculus lawrencei by original designation)

C. lawrencei Coineau, 1974a

Microcaeculus Franz, 1952 (type species Microcaeculus austriacus by original designation)

= Sclerocaeculus Coineau, 1974a (unavailable name)

M. andrei (Lawrence, 1939)

= Caeculus andrei Lawrence, 1939

M. austriacus Franz, 1952

M. canariensis Franz, 1965

M. castrii Franz, 1964

M. deserticolus (Lawrence, 1939)

= Caeculus deserticolus Lawrence, 1939

= Sclerocaeculus deserticolus (Lawrence, 1939)

M. franzi Coineau, 1968

M. graecus Franz, 1964

M. hispanicus Franz, 1952

M. insolitus (André, 1935)

= Caeculus insolitus André, 1935 [also described as new in André, 1936]

M. insularis Franz, 1964

M. laoshanensis (Jacot, 1936)

= Caeculus laoshanensis Jacot, 1936

M. liguricus (Vitzthum, 1933)

= Caeculus liguricus Vitzthum, 1933

M. monticolus (Lawrence, 1939)

= Caeculus monticolus Lawrence, 1939

M. muscorum (Lucas, 1847) (see note below)

= Caeculus muscorum Lucas, 1847
M. namibensis Piffl, 1965

= Sclerocaeculus namibensis (Piffl, 1965)

M. nicoleae Coineau, 1974a

M. nudus Franz, 1964

M. pisanus (André, 1936)

= Caeculus pisanus André, 1936

M. pica Otto, 1993

M. sabulicola Franz, 1952

M. sinensis (Jacot, 1936)

= Caeculus sinensis Jacot, 1936

M. sinensis taishanicus (Jacot, 1936)

= Caeculus sinensis taishanicus Jacot, 1936

M. steineri Franz, 1955

$=M$. hispanicus steineri

M. steineri delamarei Coineau, 1974a

M. stephani Coineau and Haupt, 1977

M. tibbettsi (Higgins and Mulaik, 1958)

= Caeculus tibbettsi Higgins and Mulaik, 1958

M. uchidai (Asanuma, 1940) new combination

= Caeculus uchidai Asanuma, 1940

M. weyrauchi Franz, 1964

Neocaeculus Coineau, 1967a (type species Neocaeculus luxtoni by monotypy)

N. bornemisszai Coineau and Enns, 1969

N. bruchi (Berlese, 1916)

= Caeculus bruchi Berlese, 1916

$N$. imperfectus new species

N. johnstoni Coineau, $1974 \mathrm{~b}$

N. knoepffleri Coineau and Enns, 1969

N. lamorali Coineau, 1974a

N. luxtoni Coineau, 1967a

N. womersleyi Coineau, 1974b

Procaeculus Jacot, 1936 (type species Procaeculus bryani by monotypy)

P. bryani Jacot, 1936

P. brevis (Mulaik, 1945)

= Caeculus brevis Mulaik, 1945

†P. dominicensis Coineau and Poinar, 2001 
†P. eridanosae Coineau and Magowski, 1994

P. magnus Coineau, 1974a

P. mexicanus (Mulaik and Allred, 1954)

= Caeculus mexicanus Mulaik and Allred, 1954

P. orchidicolis (Mulaik and Allred, 1954)

= Caeculus orchidicolis Mulaik and Allred, 1954

P. oregonus (Mulaik and Allred, 1954)

= Caeculus oregonus Mulaik and Allred, 1954

P. potosi (Mulaik and Allred, 1954)

= Caeculus potosi Mulaik and Allred, 1954

P. puertoricus (Mulaik, 1945)

= Caeculus puertoricus Mulaik, 1945

P. willmanni (Vitzthum, 1933)

= Caeculus willmanni Vitzthum, 1933

= Procaeculus aitkeni Coineau, 1967b (see

note below)

Names of uncertain status:

Caeculus spathuliger [sic] var. calidior Berlese, 1916: Berlese proposed this as a possible name for a specimen from Somalia, but declined to formally establish it until further specimens became available for comparison. As this name does not appear to have been used by any subsequent authors, we believe it is best treated as a nomen nudum.

Caeculus hirtipes Berlese, 1910: The description of this species given by Berlese is probably inadequate for its identification, and Franz (1952) listed it as a species incertae sedis within Caeculidae. Similarly unidentifiable is the form described as C. hirtipes var. graecus Berlese, 1910.

Notes:

Microcaeculus muscorum: The publication history of Lucas (1846-1849) has been analysed by Evenhuis (2012). The section including the description of Caeculus muscorum (as Coeculus muscorum) had most likely been distributed by 15 May 1847.
Procaeculus aitkeni: Despite being described as a new species in Coineau (1969a), a preliminary description of this species had already appeared in Coineau (1967b). Coineau (1969a) noted that this species was uncertainly distinct from Procaeculus willmanni (Vitzthum 1933); though a formal synonymy of the two species was never published, Coineau (1974a) later reproduced figures of P. aitkeni from Coineau (1969a) labelled as P. willmanni.

\section{ACKNOWLEDGEMENTS}

We would like to thank Yves Coineau for his helpful correspondence in compiling the checklist of Caeculidae. Two anonymous reviewers provided invaluable guidance in composing the manuscript. Thank you also to Jonathan Majer, Karl Edwards, Brad Scanlon and Morgan Lythe for their work on the current project. Research was conducted and funded as part of the Gorgon Project, which is operated by an Australian subsidiary of Chevron and is a joint venture of the Australian subsidiaries of Chevron (approximately 47 percent), ExxonMobil (25 percent) and Shell (25 percent), Osaka Gas (1.25 percent), Tokyo Gas (one percent) and Chubu Electric Power (0.417 percent).

\section{REFERENCES}

André M. 1935 - Une espèce nouvelle du genre Caeculus (Acariens) recueillie aux Îles Salvages - Bulletin du Muséum National d’Histoire Naturelle, 2e sér., 7, 2: 113-118.

André M. 1936 - Notes sur le genre Caeculus Dufour (Acariens) avec description d'espèces nouvelles africaines - Bulletin de la Société d'Histoire Naturelle de l'Afrique du Nord, 26: 79-127.

André M. 1938 — Une nouvelle espèce sénégalaise du genre Caeculus (Acarien) - Bulletin de la Société Zoologique de France, 63: 264-269.

Asanuma K. 1940 - Occurrence of Acari of the family Caeculidae in Japan - Annotationes Zoologicae Japonenses, 19, 4: 271-275.

Banks N. 1899 - An American species of the genus Caeculus - Proceedings of the Entomological Society of Washington, 4: 221-222. 
Banks N. 1905 - Descriptions of some new mites - Proceedings of the Entomological Society of Washington, 7: 135-136.

Berlese A. 1916 - Centuria terza di Acari nuovi - Redia, 12: 289-338.

Callan S.K., Majer J.D., Edwards K., Moro D. 2011 Documenting the terrestrial invertebrate fauna of Barrow Island, Western Australia - Australian Journal of Entomology, 50: 323-343. doi:10.1111/j.14406055.2011.00818.x

Canestrini G., Fanzago F. 1877 - Sul genere Caeculus, Duf. - Atti del Reale Istituto Veneto di Scienze, Lettere ed Arti, ser. 5, 3: 477-482.

Coineau Y. 1967a - Contribution à l'étude des Caeculidae. Troisième série. Développement postlarvaire de Neocaeculus luxtoni n. gen., n. sp. - Acarologia, 9, 1: 55-75.

Coineau Y. 1967b - Contribution à l'étude des Caeculidae. IV. Procaeculus bryani Jacot, 1936 (Acariens, Prostigmates) - Pacific Insects, 9, 4: 709-720.

Coineau Y. 1968 - Contribution à l'étude des Caeculidae. 7e série. Microcaeculus franzi n. sp., Caeculidae sabulicole de Corse - Vie et Milieu, Série C, Biologie Terrestre, 19, 1: 143-158.

Coineau Y. 1969a - Contribution à l'étude des Caeculidae. Cinquième série. Procaeculus aitkeni, une nouvelle espèce de Trinidad, B. W. 1. - Revue d'Ecologie et de Biologie du Sol, 6, 1: 53-67.

Coineau Y. 1969b - Contribution à l'étude des Caeculidae. Sixième série. Microcaeculus sabulicola Franz 1952. Redescription, chétotaxie et répartition - Acarologia, 11, 2: 207-221.

Coineau Y. 1974a - Éléments pour une monographie morphologique, écologique et biologique des Caeculidae (Acariens) - Mémoires du Muséum National d'Histoire Naturelle, Série A, Zoologie, 81: 1-299, pls $1-24$.

Coineau Y. 1974b - Contribution à l'étude des Caeculidae. Neuvième partie. Deux nouvelles espèces de Caeculidae de la région Australienne Neocaeculus johnstoni n.sp. et N. womersleyi n.sp. - Vie et Milieu, 24, 1: 65-86.

Coineau Y., Enns W.R. 1969 - Contribution à l'étude des Caeculidae (Acariens, Prostigmates). 8e série. Deux nouvelles espèces d'Australie: Neocaeculus knoepffleri n. sp.; N. bornemisszai n. sp. - Acarologia, 11, 4: 207221.

Coineau Y., Haupt J. 1977 - Biogéographie, écologie et chétotaxie évolutive a propos des Microcaeculus stephani n. sp. Caeculidae sabulicole (Acari, Actinedida) - Acarologia, 19, 4: 622-632.
Coineau Y., Magowski W.Ł. 1994 - Caeculidae in amber - Acarologia, 35, 3: 243-246.

Coineau Y., Poinar G. 2001 - Un Caeculidae de l'ambre de la République Dominicaine - Acarologia, 41, 1-2: 141-144.

Dufour L. 1832 - Description et figure du Caeculus echinipes, Arachnide nouvelle - Annales des Sciences Naturelles, sér. 1, 25: 289-296, pl. 9. figs 1-3.

Enns W.R. 1958 - A new species of rake-legged mite from Missouri (Acarina, Caeculidae) - Journal of the Kansas Entomological Society, 31, 2: 107-113.

Evenhuis N.L. 2012 - Publication and dating of the "Exploration Scientifique de l'Algérie: Histoire Naturelle des Animaux Articulés (1846-1849)" by Pierre Hippolyte Lucas - Zootaxa, 3448: 1-61.

Franz H. 1952 - Revision der Caeculidae Berlese 1883 (Acari) - Bonner Zoologische Beiträge, 3, 1-2: 91-124.

Franz H. 1954 - Eine weitere neue Allocaeculus-Art nebst Bemerkungen über bekannte Vertreter der Caeculidae (Acari) - Bonner Zoologische Beiträge, 5, 3-4: 210212.

Franz H. 1955 - Dritter Beitrag zur Kenntnis der Caeculidae (Acari) - Verhandlungen der ZoologischBotanischen Gesellschaft in Wien, 95: 9-18.

Franz H. 1957 - Zur Kenntnis der afrikanischen Arten der Gattung Allocaeculus (Acari, Trombidiformes) - Verhandlungen der Zoologisch-Botanischen Gesellschaft in Wien, 97: 5-13.

Franz H. 1960 - Weitere Beiträge zur Kenntnis der europäischen und nordafrikanischen Caeculidae (Acari, Trombidiformes) - Verhandlungen der ZoologischBotanischen Gesellschaft in Wien, 100: 83-87.

Franz H. 1962 - Ein neuer Microcaeculus aus Südamerika. (Acari, Trombidiformes) - Verhandlungen der Zoologisch-Botanischen Gesellschaft in Wien, 101102: 98-100.

Franz H. 1964 - Neue Caeculiden aus Afrika und Südamerika - Verhandlungen der ZoologischBotanischen Gesellschaft in Wien, 103-104: 82-93.

Franz H. 1965 - 2. Beitrag zur Bodenfauna der Kanarischen Inseln. Caeculiden von Tenerife (Acari, Trombidiformes) - Verhandlungen der ZoologischBotanischen Gesellschaft in Wien, 105-106: 67-69.

Hagan D.V. 1985 - Caeculus crossleyi n. sp. (Acari: Caeculidae) from granite outcrops in Georgia, U.S.A. International Journal of Acarology, 11, 4: 241-245. doi:10.1080/01647958508683424

Higgins H.G., Mulaik S.B. 1957a - A new Caeculus from Oregon (Acarina: Caeculidae) - Great Basin Naturalist, 17, 1-2: 27-29.

Higgins H.G., Mulaik S.B. 1957b - Another Caeculus from southwestern United States (Acarina Caeculidae) - Texas Journal of Science, 9: 267-269. 
Higgins H.G., Mulaik S.B. 1958 - A new Korean mite (Acarina, Caeculidae) - Proceedings of the Entomological Society of Washington, 60, 1: 17-18.

International Commission on Zoological Nomenclature. 1999 - International Code of Zoological Nomenclature, 4th ed. London: International Trust for Zoological Nomenclature. pp. 306.

Jacot A.P. 1936 - Some rake-legged mites of the family Cheyletidae - Journal of the New York Entomological Society, 44, 1: 17-30.

Karpelles L. 1893 - Bausteine zu einer Acarofauna Ungarns - Mathematische und Naturwissenschaftliche Berichte aus Ungarn, 11: 80-134, pls 13-20.

Kulczyński W. 1901 - Arachnoidea - In: Horváth G. (ed.) Zichy Jenő Gróf Harmadik Ázsiai Utazása [Dritte Asiatische Forschungsreise des Grafen Eugen Zichy] vol 2. Állattani Eredményei [Zoologische Ergebnisse]. Budapest \& Leipzig. pp. 311-369, pls 12-13.

Lawrence R.F. 1938 - A new species of Caeculus (Acari) from South-West Africa - Annals of the Transvaal Museum 19 (2): 211-213.

Lawrence R.F. 1939 - New South African species of the genus Caeculus (Acari) - Journal of the Linnean Society of London, Zoology, 40, 273: 537-545.

Lucas P.H. 1846-1849 - Exploration scientifique de l'Algérie pendant les années 1840, 1841, 1842 publiée par ordre du gouvernement et avec le concours d'une commission académique. Sciences Physiques. Zoologie. Histoire Naturelle des Animaux Articulés. Première Partie. Crustacés, Arachnides, Myriapodes et Hexapodes. Paris: Imprimerie Nationale.

McDaniel B., Boe A. 1990 - A new species and distribution record for the genus Caeculus Dufour (Acari: Caeculidae) from South Dakota - Proceedings of the Entomological Society of Washington, 92, 4: 716-724.

Michael A.D. 1890 - On a collection of Acarina formed in Algeria - Proceedings of the Zoological Society, 1890, 29: 423-425.

Mulaik S. 1945 - New mites in the family Caeculidae Bulletin of the University of Utah, 35, 17: 1-23.

Mulaik S., Allred D.M. 1954 - New species and distribution records of the genus Caeculus in North America -
Proceedings of the Entomological Society of Washington, 56: 27-40.

Nevin R.R. 1943 - Caeculus pettiti, a new species of mite from Virginia - Annals of the Entomological Society of America, 36, 3: 389-393.

Otto J.C. 1993 - A new species of Microcaeculus from Australia (Acarina: Caeculidae), with notes on its biology and behavior - International Journal of Acarology, 19, 1: 3-13. doi:10.1080/01647959308683533

Piffl E. 1959 - Allocaeculus indicus, ein neuer Caeculidae aus Pakistan (Caeculidae, Trombidiformes, Acari) - Verhandlungen der Zoologisch-Botanischen Gesellschaft in Wien, 98-99: 52-56.

Piffl E. 1965 - Microcaeculus namibensis nov. spec. Ein Vertreter der Caeculiden (Arachnoidea, Acarina) aus der Namibwüste Südwestafrikas - Scientific Papers of the Namib Desert Research Station, 28, 1-12.

Trägardh I. 1905 - Acariden aus Ägypten und dem Sudan. Zugleich ein Beitrag zur Kenntnis der Entwicklungsgeschichte der Gattungen Phytoptipalpus, Pimeliaphilus, Pterygosoma und Podapolipus. I. Teil Results of the Swedish Zoological Expedition to Egypt and the White Nile, 1901, under the direction of L. A. Jägerskiöld, Part II, 20: 1-124, i-iv, A-H, a-b, 6 pls.

Vitzthum H.G. 1933 - Die Larvenform der Gattung Caeculus Dufour — Zoologischer Anzeiger, 105: 85-92.

Walter D.E., Lindquist E.E., Smith I.M., Cook D.R., Krantz G. W. 2009 - Order Trombidiformes - In: Krantz G.W., Walter D. E. (Eds). A Manual of Acarology, 3rd ed. Lubbock, Texas: Texas Tech University Press. pp. 233-420.

\section{COPYRIGHT}

(oc) EY-No-ND Taylor C.K. et al. Acarologia is under free license. This open-access article is distributed under the terms of the Creative Commons-BY-NC-ND which permits unrestricted non-commercial use, distribution, and reproduction in any medium, provided the original author and source are credited. 